\title{
PENGARUH TRANSAKSI NON TUNAI, INFLASI DAN PENERIMAAN PAJAK TERHADAP PERUMBUHAN EKONOMI DI INDONESIA
}

\author{
Merin Tri Lestari ${ }^{1 *}$, Adi Irawan Setiyanto ${ }^{2)}$ \\ ${ }^{1}$ Manajemen Bisnis, Politeknik Negeri Batam \\ email: merintri@gmail.com \\ ${ }^{2}$ Manajemen Bisnis, Politeknik Negeri Batam \\ email: adiirawan@polibatam.ac.id
}

\begin{abstract}
Economic growth is a development goal that every country wants to achieve, one of which is Indonesia, which is currently focus on increasing economic growth. Therefore, this study aims to analyze the effect of ATM and debit cards, electronic money, inflation and tax revenue on economic growth in Indonesia, either partially or simultaneously. This type of research uses a quantitative approach with multiple linear regression methods, data used are secondary data taken from the publications of the Central Statistics Agency, Bank Indonesia and the Ministry of Finance of the Republic of Indonesia in 2012-2018. The data in the study were processed using SPSS 26. Results of hypothesis testing showed that ATM and debit cards had a positive effect on economic growth, electronic money had a positive effect on economic growth. While inflation has no effect on economic growth and tax revenue has no effect on economic growth. Simultaneously, ATM and debit cards, electronic money, inflation and tax revenues have an effect on economic growth.
\end{abstract}

Keywords: ATM and Debit Cards, Economic Growth, Inflation, Tax Revenue, Electronic Money

\begin{abstract}
ABSTRAK
Pertumbuhan ekonomi menjadi tujuan pembangunan yang ingin dicapai oleh setiap negara salah satunya Indonesia yang sedang berfokus dalam peningkatan pertumbuhan ekonomi. Oleh sebab itu penelitian ini bertujuan untuk menganalisis pengaruh kartu ATM dan debit, uang elektronik, inflasi dan penerimaan pajak terhadap pertumbuhan ekonomi di Indonesia baik secara parsial maupun simultan. Jenis penelitian ini menggunakan pendekatan kuantitatif dengan metode regresi linear berganda, data yang digunakan yaitu data sekunder diambil dari publikasi Badan Pusat Statistik, Bank Indonesia dan Kementrian Keuangan Republik Indonesia tahun 2012-2018. Data dalam penelitian diolah menggunakan SPSS 26. Hasil pengujian hipotesis menunjukkan bahwa kartu ATM dan debit berpengaruh positif terhadap pertumbuhan ekonomi, uang elektronik berpengaruh positif terhadap pertumbuhan ekonomi. Sedangkan inflasi tidak berpengaruh terhadap pertumbuhan ekonomi dan penerimaan pajak tidak berpengaruh terhadap pertumbuhan ekonomi. Secara simultan kartu ATM dan debit, uang elektronik, inflasi dan penerimaan pajak berpengaruh terhadap pertumbuhan ekonomi
\end{abstract}

Kata Kunci: Kartu ATM dan Debit, Pertumbuhan Ekonomi, Inflasi, Penerimaan Pajak, Uang Elektronik

*Corresponding author. E-mail: merintri@gmail.com 


\section{PENDAHULUAN}

Ekonomi makro pada dasarnya merupakan sebuah teori yang bertujuan untuk mempelajari tentang perubahan ekonomi suatu negara dan kemudian mencari solusi dari masalah yang timbul dalam perekonomian dengan memperbaiki kebijakan ekonomi yang ada. Indonesia merupakan negara berkembang yang sedang berfokus dalam peningkatan pertumbuhan ekonomi. Pertumbuhan ekonomi adalah kondisi di mana aktivitas perekonomian mengalami peningkatan jumlah produksi barang dan jasa, ditandai dengan peningkatan output per kapita dalam jangka panjang. Perekonomian tanpa adanya pertumbuhan ekonomi yang meningkat akan berjalan ditempat atau mengalamai stagnasi dan akhirnya tidak akan tercipta kesejahteraan. Tingkat pertumbuhan ekonomi disajikan dalam bentuk persentase yang mengukur perubahan kondisi perekonomian dari tahun ke tahun. Indikator yang digunakan untuk melihat perekonomian suatu negara adalah Produk Domestik Bruto (PDB) yang dihasilkan dari jumlah nilai barang dan jasa seluruh unit ekonomi selama periode tertentu.

Data BPS menunjukkan presentase laju pertumbuhan ekonomi Indonesia yang setiap tahunnya mengalami fluktuasi, salah satu faktor yang mempengaruhi kondisi tersebut yaitu permintaan agregat, sesuai dengan hukum permintaan di mana jika harga naik maka permintaan akan turun dan begitu juga sebaliknya. Peran pemerintah diperlukan dalam meningkatkan pertumbuhan ekonomi melalui kebijakan fiskal dan kebijakan moneter yang diterapkan untuk menurunkan inflasi dan mengatasi pengangguran. Ilmu pengetahuan serta teknoIogi menjadi faktor yang mempengaruhi pertumbuhan ekonomi. Perkembangan teknologi yang pesat berdampak pada kegiatan ekonomi, akibatnya alat pembayaran yang digunakan dalam transaksi terus mengalami perubahan. Salah satunya adalah perubahan pada sistem pembayaran yang menjadi bagian sangat penting dalam infrastruktur keuangan karena mengatur transaksi dalam perekonomian. Perkembangan sistem pembayaran menggantikan peran uang kertas atau uang tunai menjadi alat pembayaran non tunai, dengan manfaat yang diberikan dari non tunai tersebut mempermudah masyarakat dalam melakukan transaksi karena lebih praktis, aman dan efisien (Ismanda, 2019). Data BPS memperlihatkan bahwa dari tahun 2015 sampai 2019 jumlah transaksi tanpa uang tunai meliputi penggunaan uang elektronik atau e-money serta kartu ATM dan debit selalu mengalami peningkatan setiap tahunnya. Banyaknya jumlah permintaan, penawaran pada barang dan jasa menentukan tingkat laju inflasi. Inflasi merupakan suatu kondisi kenaikan tingkat harga secara umum, tingginya inflasi dapat menghambat aktivitas perekonomian dan pengangguran yang meningkat. Diperlukan upaya untuk menjaga kestabilan inflasi pada level yang rendah, sehingga dapat membawa dampak positif terhadap perekonomian.

Perkembangan pendapatan nasional juga dipengaruhi oleh penerimaan pajak. Penerimaan pajak akan mendorong perekonomian karena dana tersebut akan dialokasikan untuk penyelenggaraan negara, termasuk pembangunan yang bertujuan untuk menciptakan kesejahteraan rakyat. Untuk meningkatkan penerimaan perpajakan pemerintah melakukan reformasi pajak demi terciptanya kesejahteraan masyarakat melalui pertumbuhan ekonomi. Reformasi perpajakan dikatakan berhasil jika bersih dari korupsi, kualitas pelayanan publik yang baik serta prosedur perpajakan yang lebih efisien dan efektif dengan tujuan mempermudah wajib pajak dalam melakukan pembayaran pajak (Saragih, 2018). Perkembangan ekonomi sejalan dengan penerimaan pajak, semakin tingginya kegiatan ekonomi akan mengakibatkan pungutan pajak meningkat walaupun tarif pajak tidak mengalami 
perubahan sehingga diikuti dengan peningkatan pengeluaran pemerintah.

Penelitian terkait pertumbuhan ekonomi bukanlah penelitian baru dan telah dilakukan secara luas dengan hasil yang sangat beragam. Penelitian yang dilakukan oleh Sumon \& Miyan (2017) bertujuan untuk mengetahui pengaruh inflasi terhadap pertumbuhan ekonomi di Bangladesh, riset tersebut menemukan hasil bahwa terdapat pengaruh positif antara inflasi dan pertumbuhan ekonomi dengan ambang batas inflasi 9\%. Penelitian lain juga pernah dilakukan di Indonesia oleh Yulianti \& Khairuna (2019) hasil riset tersebut menjelaskan bahwa inflasi memiliki pengaruh positif terhadap perekonomian di Provinsi Aceh, akan tetapi jika laju inflasi nilainya melebihi $10 \%$ akan berdampak buruk pada perekonomian. Riset berikutnya dilakukan oleh Marginingsih \& Sari (2019) yang meneliti bagaimana pengaruh transaksi non tunai dengan indikator penggunaan uang elektronik dan kartu ATM terhadap pertumbuhan ekonomi. Riset tersebut menemukan hasil bahwa seluruh variabel bebas memiliki pengaruh positif yang signifikan terhadap pertumbuhan ekonomi. Efek positif dari penggunaan instrumen pembayaran non tunai berkaitan dengan manfaat yang ditawarkan seperti aspek kemudahan, keamanan dan kenyamanan dalam bertransaksi. Penelitian selanjutnya dilakukan oleh Sumaryani (2019) menyimpulkan bahwa pertumbuhan ekonomi dapat ditingkatkan dengan cara memaksimalkan perolehan realisasi pajak nasional yang menjadi sumber pembiayaan pembangunan, mengendalikan dan mengontrol tingkat inflasi dan memperbaiki pendidikan sehingga meningkatkan sumber daya manusia sebagai perlaku ekonomi. Penelitian ini merupakan pengembangan dari penelitian sebelumnya dengan menambahkan transaksi non tunai dan penerimaan pajak sebagai variabel independen.

\section{KAJIAN LITERATUR}

\section{Teori Difusi Inovasi}

Teori ini dikemukakan oleh Roger yang menjelaskan bagaimana sebuah inovasi dan teknologi baru dikomunikasikan atau disampaikan melalui berbagai saluran dalam jangka waktu tertentu, kemudian inovasi tersebut akan diadopsi oleh anggota sistem sosial atau sekelompok orang yang memiliki tujuan sama. Teori ini juga dijelaskan dalam penelitian Tee \& Ong (2016) menjelaskan sebuah inovasi akan tersebar ke seluruh masyarakat setelah mereka mendengar atau mengetahui inovasi tersebut, meskipun tidak dalam jangka waktu yang sama inovasi akan diadopsi oleh seluruh masyarakat. Berdasarkan teori tersebut dikaitkan dengan penyebaran dan penerapan sistem pembayaran non tunai di mana sebagian kalangan masyarakat sekarang lebih memilih transaksi yang cepat, aman dan efisien. Teori difusi inovasi dalam transaksi non tunai tergantung seberapa cepat masyarakat mengadopsi inovasi tersebut dengan beralih dari transaksi tunai menggunakan transaksi non tunai.

\section{Teori Ekonomi Keynes}

Dalam Teori ini dikemukakan oleh Keynes dalam Permatasari (2020) yang terkenal dengan teori liquidity preference, menjelaskan bahwa ada 3 motif ketika seseorang akan melakukan pertimbangan saat memiliki uang, tujuan yang mendasari hal tersebut yaitu permintaan uang untuk transaksi, spekulasi dan berjaga-jaga.

\section{Teori Pengeluaran Pemerintah}

Teori ini dikemukakan oleh Peacock dan Wiseman dalam Setiabudi (2017) menjelaskan bahwa pengeluaran pemerintah akan mendorong pertumbuhan ekonomi, sumber penerimaan pemerintah salah satunya berasal dari pajak. Akan tetapi masyarakat tidak suka membayar pajak yang semakin besar untuk membiayai pengeluaran pemerintah yang semakin besar. Setiap orang memiliki toleransi pajak 
untuk memahami besar pungutan pajak untuk membiayai aktivitas pemerintah. Jika dikaitkan dengan perpajakan masalah kepentingan terjadi karena adanya upaya menghindari pembayaran pajak oleh wajib pajak sedangkan pemerintah ingin memaksimalkan penerimaan pajak.

\section{Pembayaran Non Tunai}

Sistem pembayaran digunakan untuk melakukan pemindahan dana atau uang dari pihak yang melakukan transaksi untuk memenuhi kewajiban dari suatu kegiatan ekonomi (Lestari, 2017). Alat pembayaran digunakan sebagai media untuk melakukan berbagai macam transaksi, seiring berjalannya waktu bentuknya semakin berkembang dari alat pembayaran tunai menjadi alat pembayaran non tunai. Terjadi pergeseran instrumen pembayaran yang sebelumnya berbasis kertas seperti, giro dan cek beralih ke penggunaan berbasis elektronik dan berbasis kartu, terlihat dari semakin banyaknya masyarakat yang melakukan transaksi dengan menggunakan kartu ATM dan debit, uang elektronik dan kartu kredit (Marginingsih \& Sari, 2019).

\section{Pertumbuhan Ekonomi}

Pertumbuhan ekonomi merupakan suatu ukuran kuantitatif yang menggambarkan perubahan kondisi ekonomi suatu negara secara berkesinambungan menuju keadaan yang lebih baik selama periode tertentu. Terjadi peningkatan dalam kegiatan perekonomian yang menyebabkan kenaikan produksi barang dan jasa sehingga akan menambah output atau pendapatan nasional (Siahaan, Purba, \& Simangunsong, 2001). Pertumbuhan ekonomi diukur menggunakan nilai uang yang tercermin pada Produk Domestik Bruto (PDB) dengan melihat total output dari produksi barang dan jasa, pada umumnya perhitungannya dilakukan dalam triwulan atau tahunan kemudian dibandingkan dengan periode sebelumnya (Marginingsih \& Sari, 2019).
Marginingsih \& Sari (2019) melakukan penelitian menggunakan indikator penggunaan kartu ATM dan debit, uang elektronik dan kartu kredit pada periode tahun 2014-2018. Hasil penelitian menyimpulkan bahwa variabel independen secara simultan dan parsial memiliki pengaruh positif signifikan terhadap pertumbuhan ekonomi. Ketika terjadi kenaikan penggunaan instrumen pembayaran non tunai dalam bertransaksi akan berpengaruh pada penurunan permintaan uang di masyarakat sehingga akan menurunkan suku bunga. Manfaat yang ditawarkan dari pembayaran non tunai seperti kemudahan, keamanan dan kenyamanan dalam bertransaksi dapat meningkatkan konsumsi masyarakat.

Susilawati \& Putri (2019) meneliti bagaimana pengaruh antara transaksi non tunai dengan pertumbuhan ekonomi. Penelitian tersebut dilakukan di Indonesia dengan hasil penelitian mengungkapkan bahwa terdapat pengaruh positif antara kartu kredit dengan pertumbuhan ekonomi. Ketika volume transaksi kartu kredit naik menandakan konsumsi masyarakat meningkat dan akan menyebabkan perputaran uang lebih cepat. Saat terjadi peningkatan jumlah konsumsi perusahaan akan menambah produksi demi memenuhi permintaan konsumen. Kondisi tersebut akan meningkatkan output dan pertumbuhan ekonomi.

Penelitian terkait pertumbuhan ekonomi lainnya dilakukan oleh Yulianti \& Khairuna (2019) dengan tujuan untuk mempelajari pengaruh inflasi terhadap pertumbuhan ekonomi, penelitian dilakukan di Provinsi Aceh. Produk Domestik Bruto digunakan sebagai indikator tingkat pertumbuhan ekonomi dan inflasi pada penelitian tersebut diukur menggunakan Indeks Harga Konsumen. Pengujian hipotesis menggunakan regresi linear sederhana dengan sumber data sekunder dari BPS tahun 2015-2018. Penelitian tersebut menyatakan terdapat pengaruh yang positif secara statistik antara inflasi terhadap pertumbuhan ekonomi. 
Penelitian terkait pertumbuhan ekonomi lainnya dilakukan oleh Saragih (2018) yang bertujuan untuk mengetahui bagaimana pengaruh penerimaan pajak terhadap pertumbuhan ekonomi di Indonesia dengan menggunakan data 34 provinsi pada periode 2013-2016. Hasil riset tersebut menyimpulkan bahwa adanya pengaruh yang positif dan signifikan antara penerimaan pajak tehadap pertumbuhan ekonomi. Pemerintah perlu meningkatkan reformasi pajak dan wajib pajak juga harus terus meningkatkan kepatuhan membayar pajak. Penerimaan pajak digunakan untuk mendanai proyek yang produktif sehingga akan mempercepat pertumbuhan ekonomi.

Hubungan antara pengaruh transaksi non tunai dengan pertumbuhan ekonomi dalam penelitian terdahulu ditemukan terdapat pengaruh yang positif. Dijelaskan dalam hasil penelitian yang dilakukan oleh Marginingsih \& Sari (2019) menyimpulkan bahwa masing-masing transaksi menggunakan kartu dan uang elektronik berpengaruh positif signifikan terhadap pertumbuhan ekonomi, semakin tinggi nilai transaksi menggunakan uang elektronik dan kartu ATM dan debit maka pertumbuhan ekonomi semakin meningkat. Semakin banyak masyarakat yang menggunakan kartu ATM dan debit akan mengakibatkan penurunan permintaan uang. Manfaat yang ditawarkan dalam bertransaksi non tunai akan meningkatkan perputaran uang yang berdampak pada pertumbuhan ekonomi (Sreenu, 2020). Perubahan bentuk uang tunai menjadi non tunai mempermudah dalam melakukan transaksi karena lebih praktis, efisien dan aman (Febriaty, 2019). Terdapat faktor lain yang mempengaruhi tingkat pertumbuhan ekonomi yaitu inflasi. Penelitian Yulianti \& Khairuna (2019) menyatakan terdapat pengaruh positif terhadap pertumbuhan ekonomi, ketika inflasi mengalami kenaikan maka akan diikuti dengan peningkatan pertumbuhan ekonomi. Akan tetapi perekonomian menjadi melemah jika inflasi terlalu tinggi, karena daya beli masyarakat akan menurun jika terjadi kenaikan harga (Kalsum, 2017).

Penerimaan pajak juga menjadi faktor yang mempengaruhi pertumbuhan ekonomi, ditemukan dalam penelitan Saragih (2018) menyatakan penerimaan pemerintah dari sektor perpajakan sangat berkontribusi terhadap pertumbuhan ekonomi di suatu daerah maupun negara. Penerimaan pajak digunakan untuk mendanai proyek yang produktif akan mempercepat pertumbuhan ekonomi. Berdasarkan uraian tersebut peneliti menduga pertumbuhan ekonomi dipengaruhi oleh penerimaan pajak, inflasi dan volume transaksi non tunai, yang diwakili oleh kartu ATM dan debit dan uang elektronik. Maka peneliti mengajukan beberapa hipotesis yaitu:

$\mathbf{H}_{1}$ : Nilai transaksi menggunakan ATM dan debit berpengaruh positif terhadap pertumbuhan ekonomi.

H2: Nilai transaksi menggunakan uang elektronik berpengaruh positif terhadap pertumbuhan ekonomi.

H3: Inflasi berpengaruh positif terhadap pertumbuhan ekonomi.

H4: Penerimaan pajak berpengaruh positif terhadap pertumbuhan ekonomi.

Berikut adalah model penelitian ini:

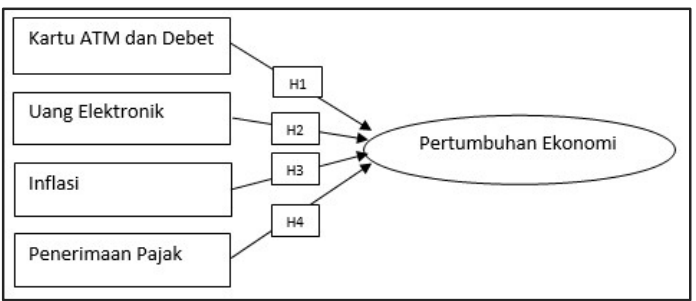

Gambar 1. Model Penelitian

\section{METODE PENELITIAN}

Penelitian ini menggunakan pendekatan kuantitatif, dimana data tersebut bersumber dari website resmi Bank Indonesia, Badan Pusat Statistik dan Kementrian Keuangan. Ojek penelitian berupa laporan triwulanan transaksi kartu ATM dan debit, uang 
elektronik, inflasi, APBN dan Produk Domestik Bruto yang diterbitkan oleh Badan Pusat Statistik, Bank Indonesia dan Kementrian Keuangan Republik Indonesia dari tahun 2012-2019. Teknik penarikan sampel yang digunakan yaitu teknik non probability sampling dengan memilih sampling jenuh atau sensus, karena semua anggota populasi akan digunakan sebagai sampel.

\section{HASIL DAN PEMBAHASAN}

\begin{tabular}{rrrrrr}
\multicolumn{5}{c}{ Tabel 1. Statistik Deskriptif } \\
\hline & N & \multicolumn{1}{c}{ Minimum } & \multicolumn{1}{c}{ Maximum } & \multicolumn{1}{c}{ Mean } & \multicolumn{1}{c}{ Std. Deviation } \\
\hline X1 & 32 & 696503539959692 & 1888459918440000 & 1326067450398580 & 369804381943716 \\
X2 & 32 & 324788999275 & 49421548590000 & 7320055449044 & 13122181135795 \\
X3 & 32 & $-0,43$ & 4,43 & 1,13 & 0,99 \\
X & 32 & 198723558195 & 603823900000 & 319858846235 & 91195821896 \\
Y & 32 & 1855580200000 & 2818887400000 & 2317285856250 & 273241726336 \\
\hline
\end{tabular}

Sumber: Output SPSS, 2021

Tabel diatas terlihat penggambaran data melalui nilai standar deviasi, rata-rata, nilai tertinggi dan terendah masing-masing variabel yang digunakan dalam penelitian.

Tabel 2. Uji Normalitas

\begin{tabular}{ccc}
\hline Keterangan & Signifikansi & Kesimpulan \\
\hline $\begin{array}{c}\text { Asymp.sig: ( } 2 \\
\text { tailed) }\end{array}$ & 0.082 & $\begin{array}{c}\text { Berdistribusi } \\
\text { Normal }\end{array}$ \\
\hline
\end{tabular}

Sumber: Output SPSS, 2021

Tabel 2. didapatkan bahwa nilai signifikansi ialah 0.082 lebih besar dari 0.05 sehingga disimpulkan data lulus uji normalitas.

Tabel 3. Uji Multikolinieritas

\begin{tabular}{lcc}
\hline & Tolerance & VIF \\
\hline Kartu ATM dan & 0.387 & 2,587 \\
Debit & 0.484 & 2,066 \\
Uang Elektronik & 0.893 & 1,120 \\
Inflasi & 0.517 & 1,934 \\
Penerimaan Pajak &
\end{tabular}

Sumber: Output SPSS, 2021

Hasil pengujian pada tabel 3. memaparkan nilai VIF keempat variabel yaitu kurang dari 10, hasil menunjukkan variabel bebas penelitian terbebas dari multikolinieritas.

\section{Tabel 4. Uji Autokorelasi}

Durbin-Watson 2,138

Sumber: Output SPSS, 2021
Tabel 4. memaparkan nilai DW hitung sejumlah 2,138. Nilai tersebut kemudian dibandingkan dengan nilai dU dan 4-dU dengan nilai $\mathrm{n}=32$ dan $\mathrm{K}=4$ yang ada dalam tabel DW pada tingkat $\alpha=5 \%$. Dari tabel tersebut terlihat nilai $\mathrm{dU}=1,7323 \mathrm{dan}$ nilai $4-\mathrm{Du}=2,2677$. Dari hasil tersebut didapatkan $1,7323<2,138<2,2677$ nilai DW lebih besar dari dU dan kurang dari 4dU maka dikatakan tidak ada masalah autokorelasi.

\section{Tabel 5. Uji Heteroskedastisitas}

\begin{tabular}{lc}
\hline \multicolumn{1}{c}{ Variabel } & Sig. \\
\hline Kartu ATM dan Debit & 0.137 \\
Uang Elektronik & 0.933 \\
Inflasi & 0.809 \\
Penerimaan Pajak & 0.157 \\
\hline
\end{tabular}

Sumber: Output SPSS, 2021

Tabel 5. memaparkan nilai signifikansi dari setiap variabel bebas $>0.05$, maka dikatakan tidak ada masalah heteroskedastisitas pada penelitian ini.

\section{Tabel 6. Uji Hipotesis}

\begin{tabular}{lr}
\hline \multicolumn{1}{c}{ Variabel } & \multicolumn{2}{c}{ Unstandardized } \\
& \multicolumn{2}{c}{ Coefficients } \\
\hline (Constant) & 1404510993357.535 \\
Kartu ATM dan & 0.001 \\
Debit & 0.002 \\
Uang Elektronik & -4485518574.590 \\
Inflasi & -0.041 \\
Penerimaan Pajak &
\end{tabular}

Sumber: Output SPSS, 2021

Berdasarkan hasil analisis regresi tersebut, maka model persamaan regresi yang diperoleh adalah:

$\mathrm{Y}=1404510993357.535+0.001 \mathrm{X} 1+0.02$

X2 - 4485518574.590 X3 - 0.041 X4

Persamaan model regresi di atas maka dapat disimpulkan bahwa jika variabel independen bernilai konstanta maka nilai pertumbuhan ekonomi akan berganti menjadi nilai konstanata yakni 1404510993357.535. Variabel kartu ATM dan debit apabila mengalami kenaikan satu satuan, sementara variabel lainnya bernilai konstan maka akan terjadi perubahan pada pertumbuhan ekonomi sebesar 0.001 . 
Selanjutnya variabel uang elektronik, apabila meningkat satu satuan dan varibel independen lainnya bernilai konstan maka pertumbuhan ekonomi akan mengalami perubahan menjadi 0.002. Berikutnya untuk variabel X3 yaitu inflasi, apabila terjadi peningkatan untuk setiap satu satuan dan variabel bebas lainnya bernilai konstan maka pertumbuhan ekonomi akan mengalami perubahan sebesar 485518574.590. Berikutnya untuk variabel penerimaan pajak, apabila mengalami kenaikan satu satuan dan variabel independen lainnya bernilai konstan maka akan terjadi perubahan sebesar -0.041 pada pertumbuhan ekonomi.

\section{Tabel 7. Uji Parsial T}

\begin{tabular}{lcc}
\hline \multicolumn{1}{c}{ Variabel } & \multicolumn{1}{c}{$\mathrm{T}$} & Sig. \\
\hline (Constant) & 36.660 & 0.000 \\
Kartu ATM dan & 22.991 & 0.000 \\
Debit & & \\
Uang Elektronik & 2.214 & 0.035 \\
Inflasi & -0.603 & 0.552 \\
Penerimaan Pajak & -0.386 & 0.702 \\
\hline umber: Output SPSS, 2021
\end{tabular}

Berdasarkan hasil pengujian di atas dapat disimpulkan bahwa:

Hasil Pengujian Hipotesis Pertama:

Nilai signifikansi dari tabel 7. menjelaskan bahwa nilai untuk variabel kartu ATM dan debit 0.000 kemudian dibandingkan dengan nilai signifikansi yakni $0.000<0.05$ dan kesimpulan yang ditarik adalah variabel kartu ATM dan debit berpengaruh positif terhadap pertumbuhan ekonomi, sehingga $\mathrm{H}_{1}$ diterima. Adanya pengaruh merupakan dampak positif dari manfaat efisiensi yang diperoleh dari bertransaksi menggunakan kartu ATM dan debit. Ketika terjadi peningkatan transaksi tanpa uang tunai yaitu menggunakan kartu ATM dan debit maka akan terjadi perputaran uang yang lebih cepat, hal tersebut juga menandakan adanya peningkatan konsumsi masyarakat. Sesuai dengan teori divusi inovasi dimana masyarakat saat ini lebih tertarik untuk melakukan transaksi yang dirasa aman, cepat serta efisien. Semakin meningkatnya konsumsi masyarakat maka produksi barang dan jasa akan terus bertambah demi memenuhi permintaan konsumen. Kondisi ini akan mendorong output sehingga akan diikuti dengan meningkatnya pertumbuhan ekonomi. Hal ini juga sejalan dengan upaya perbankan menghimpun dana melalui tabungan yang menyediakan kartu ATM dan debit sebagai insentif untuk memberikan kemudahan bagi nasabah dalam melakukan transaksi.

Hasil penelitian ini sejalan dengan penelitian yang dilakukan oleh penelitian (Marginingsih \& Sari, 2019). Hasil penelitian tersebut menunjukkan bahwa kartu ATM dan debit berpengaruh positif terhadap pertumbuhan ekonomi. Pembayaran elektronik dapat meningkatkan kesejahteraan dan pertumbuhan ekonomi melalui peningkatan jumlah konsumsi masyarakat. Penelitian Ramadani, (2016) menyatakan bahwa transaksi non tunai memberikan manfaat positif bagi perekonomian karena dapat meningkatkan efisiensi dan produktivitas sektor keuangan yang kemudian akan mendorong pertumbuhan ekonomi sehingga terciptanya kesejahteraan masyarakat.

Hasil Pengujian Hipotesis Kedua:

Nilai signifikansi dari tabel 7. menjelaskan nilai untuk variabel uang elektronik 0.035 kemudian dibandingkan dengan sig yakni $0.035<0.05$ maka kesimpulan yang ditarik adalah variabel uang elektronik berpengaruh positif terhadap pertumbuhan ekonomi, sehingga $\mathrm{H}_{2} \quad$ diterima. Pertumbuhan ekonomi menjadi salah satu dampak positif dari penggunaan alat transaksi non tunai salah satunya uang elektronik yang tentunya berkaitan erat dengan manfaat yang didapatkan seperti kemudahan, kemanan dan efisien sehingga dapat meningkatkan konsumsi masyarakat. Perputaran uang akan semakin cepat dan memicu perkembangan sektor keuangan. Hasil penelitian menunjukkan bahwa pembayaran uang elektronik telah sesuai dengan teori ekonomi keynesian. Ketika 
terjadi kenaikan jumlah konsumsi yang dilakukan oleh masyarakat berdampak pada meningkatnya pendapatan nasional dan akhirnya menyumbangkan pada peningkatan sektor rill sehingga berpengaruh pada pertumbuhan ekonomi. Uang elektronik dapat meningkatkan pendapatan masyarakat karena dengan menggunakan uang eletronik biaya transaksi menurun dan waktu yang digunakan menjadi lebih efisien.

Hasil riset ini sesuai dengan riset yang dilakukan oleh Febriaty (2019) memaparkan hasil yakni uang elektronik berpengaruh positif signifikan terhadap pertumbuhan ekonomi. Produk domestik bruto berkaitan erat dengan transaksi tanpa uang tunai karena manfaat efisiensi dan produktivitas keuangan dan pada akhirnya memberikan dorongan aktivitas sektor rill, yang kemudian akan mendorong pertumbuhan ekonomi.

Hasil Pengujian Hipotesis Ketiga:

Nilai signifikansi dari tabel 7. memaparkan nilai inflasi diangka 0.552 dilakukan perbandingan dengan signifikansi yakni $0.552>0.05$ maka kesimpulan yang ditarik adalah inflasi tidak memiliki pengaruh terhadap produk domestik bruto atau pertumbuhan ekonomi, sehingga $\mathrm{H}_{3}$ ditolak. Inflasi sangat mempengaruhi nilai uang dan dampaknya akan dirasakan langsung oleh masyarakat. Tingginya tingkat laju inflasi akan mengakibatkan perekonomian semakin menurun, karena kenaikan harga berdampak pada daya beli masyarakat menurun. Selaras dengan hukum permintaan ketika naiknya harga maka penawaran atau permintaan konsumen menurun.

Tetapi dalam kondisi sekarang ini inflasi berada pada titik yang rendah yang memperlihatkan pemerintah sedang mengahadapi kesusahan mengendalikan serta meningkatkan perekonomian. Di Indonesia dari tahun 2015 tingkat inflasi berada dibawah 4\% dikarenakan fokus utama pembangunan ekonomi pada pemerataan kesejahteraan masyarakat sehingga dilakukan pengendalian harga dan mempertahankan inflasi ditingkat yang relatif rendah demi menjaga daya beli masyarakat. Konsekuensi dari inflasi yang rendah yaitu pertumbuhan ekonomi yang melambat dan relatif rendah, pertumbuhan ekonomi menurun menjadi $4,79 \%$ di tahun 2015, dengan rata-rata inflasi pertriwulan sebesar $1,1 \%$ dan bahkan terjadi deflasi di triwulan pertama tahun 2015 sebesar $0,04 \%$. Hasil penelitian ini sesuai dengan hasil riset terdahulu yang dilakukan oleh Ardiansyah (2017) memaparkan adanya pengaruh negatif antara Inflasi dan pertumbuhan ekonomi. Inflasi dapat berakibat buruk bagi suatu negara dikarenakan kenaikan harga yang terus menerus maka daya beli konsumen akan menurun.

\section{Hasil Pengujian Hipotesis Keempat:}

Nilai signifikansi dari tabel 7. menjelaskan nilai penerimaan pajak sebesar 0.702 . Nilai ini jika dibandingkan dengan nilai signifikansi yakni $0.702>0.05$ maka kesimpulan yang ditarik adalah tidak ada pengaruh yang positif antara penerimaan pajak dan pertumbuhan ekonomi, sehingga $\mathrm{H}_{4}$ ditolak. Kebijakan perpajakan yang baik ikut menentukan jalannya perekomian disuatu negara, tarif pajak yang tinggi akan menurunkan investasi yang otomatis menekan pertumbuhan ekonomi dan berdampak mengecilnya penerimaan pajak (Saragih, 2018). Hasil dari analisis berdasarkan tabel 7. menunjukkan bahwa penerimaan pajak tidak berpengaruh terhadap pertumbuhan ekonomi. Didukung oleh hasil riset yang dilakukan oleh Mahdi, Aimon, \& Syofyan (2014). Seseorang tidak melaporkan seluruh atau sebagian pendapatannya jika tarif pajak terlalu tinggi, kondisi ini juga menjadi pemicu berpindahnya investasi ke negara yang menetapkan tarif pajaknya rendah. Peacock dan wiseman mengemukakan teori pengeluaran pemerintah menyebutkan untuk bisa memahami bersarnya pungutan pajak seseorang memiliki tingkat toleransi pembayaran pajak. Inilah yang menjadi 
penghambat pemerintah dalam menaikkan pemungutan pajak.

Penurunan daya beli atau permintaan barang dan jasa yang dilakukan oleh masyarakat dikarenakan tingginya tarif pajak yang menyebabkan menurunnya pendapatan. Penurunan permintaan ini akan menyebabkan berkurangknya jumlah barang yang diproduksi dan akan mengakibatkan turunnya produk domestik bruto nasional.

\section{Tabel 8. Uji Koefisien Determinasi}

\begin{tabular}{cccc}
\hline Model & R & R Square & Adjusted R Square \\
\hline 1 & $.991^{\mathrm{a}}$ & 0.983 & 0.980
\end{tabular}

Sumber: Output SPSS, 2021

Dilihat dari nilai Ajusted $R$ Square pada tabel 8. pada angka 0.980 yang menunjukkan proporsi pengaruh variabel bebas sebesar $98 \%$ pada variabel terikat. Sisanya 2\% dipengaruhi dari faktor lain yang tidak ada pada regresi.

\section{Tabel 9. Uji Simultan}

\begin{tabular}{ccc}
\hline Model & F & Sig. \\
\hline Regression & 382.225 & $0.000^{\mathrm{b}}$ \\
\hline
\end{tabular}

Sumber: Output SPSS, 2021

Nilai F hitung (sig.) dari tabel diatas menunjukkan 0.000 lebih kecil dibandingkan dengan signifikansi, maka kesimpulan yang ditarik yakni penerimaan pajak, uang elektronik, inflasi dan kartu ATM dan debit secara simultan memiliki pengaruh terhadap variabel pertumbuhan ekonomi atau produk domestik bruto.

\section{KESIMPULAN DAN SARAN}

Setelah melakukan penelitian da menganalisis hasilnya, disimpulkan bahwa: 1. Kartu ATM dan debit secara positif mempengaruhi pertumbuhan ekonomi. Ketika transaksi kartu ATM dan debit meningkat menandakan semakin meningkatnya konsumsi masyarakat sehingga produksi barang dan jasa akan terus bertambah demi memenuhi permintaan konsumen. Kondisi ini akan mendorong output sehingga pertumbuhan ekonomi juga semakin meningkat.
2. Uang elektronik berpengaruh positif terhadap perekonomian. Pertumbuhan ekonomi menjadi dampak positif penggunaan alat transaksi non tunai salah satunya uang elektronik yang tentunya berkaitan erat dengan manfaat yang didapatkan seperti kemudahan, kemanan dan efisien sehingga dapat meningkatkan jumlah konsumsi. Apabila konsumsi masyarakat meningkat maka akan meningkatkan pendapatan nasional.

3. Inflasi tidak memiliki pengaruh pada pertumbuhan ekonomi. Tingginya tingkat inflasi menunjukkan penurunan perekonomian, fokus utama pembangunan ekonomi saat ini adalah pemerataan kesejahteraan masyarakat sehingga dilakukan pengendalian harga dan menjaga inflasi demi menjaga daya beli masyarakat. Konsekuensi dari inflasi yang rendah yaitu pertumbuhan ekonomi yang melambat.

4. Penerimaan pajak tidak berpengaruh terhadap pertumbuhan ekonomi. Turunnya pendapatan masyarakat juga desebabkan oleh kenaikan pajak sehingga akan berdampak pada daya beli masyarakat ikut menurun. Hal tersebut akan menyebabkan penurunan output sehingga akan diikuti dengan penurunan pertumbuhan ekonomi. 5. Secara simultan kartu ATM dan debit, uang elektronik, inflasi dan penerimaan pajak berpengaruh positif terhadap pertumbuhan ekonomi Indonesia.

\section{DAFTAR PUSTAKA}

Ardiansyah, H. (2017). Pengaruh Inflasi Terhadap Pertumbuhan Ekonomi di Indonesia. Jurnal Pendidikan Ekonomi. Vol. 5 No.1.

Chan, J. (2011). Cara Menulis Daftar Pustaka Yang Benar (2nd ed.). Batam: Bumi Nusantara.

Febriaty, H. (2019). Pengaruh Sistem Pembayaran Non Tunai Dalam Era Digital Terhadap Tingkat Pertumbuhan Ekonomi Indonesia. Festival Riset Ilmiah Mnajemen dan Akuntansi, 306-313. 
Ismanda, F. (2019). Analisis Pengaruh APMK dan E-money Sebagai Instrumen Pembayaran Non Tunai Terhadap Tingkat Suku Bunga dan Pertumbuhan Ekonomi Indonesia. Jurnal Dinamika Ekonomi Pembangunan. Vol. 2 No.2, 2022012.

Kalsum, U. (2017). Pengaruh

Pengangguran dan Inflasi Terhadap Pertumbuhan Ekonomi di Sumatera Utara. Jurnal Ilmu Ekonomi dan Studi Pembangunan. Vol.17 No.1.

Lestari, P. R. (2017). Perkembangan Instrumen Pembayaran Non Tunai Dalam Menyumbang Pertumbuhan Ekonomi Di Indonesia. Jurnal Ilmiah Mhasiswa FEB. Vol.5 No.2, 1-11.

Lintangsari, N. N., Hidayati, N., Purnamasari, Y., Carolina, H., \& Febranto, W. (2018). Analisis Pengaruh Instrumen Pembayaran Non Tunai Terhadap Stabilitas Sistem Keuangan Di Indonesia. Jurnal Dinamika Ekonomi Pembangunan. Vol.1 No.1, 47-62.

Mahdi, Aimon, H., \& Syofyan, E. (2014). Pengaruh Kebijakan Fiskal dan Moneter Terhadap Pertumbuhan Ekonomi Provinsi Jambi. Jurnal Kajian Ekonomi, Vol 2 No.4, 1-9.

Mahzalena, Y., \& Juliansyah, H. (2019). Pengaruh Inflasi, Pengeluaran Pemerintah dan Ekspor Terhadap Pertumbuhan Ekonomi di Indonesia. Pertumbuhan Ekonomi di Indonesia. Vol.2 No.1, 37-50.

Marginingsih, R., \& Sari, I. (2019). Nilai

Transaksi Non Tunai Terhadap Pertumbuhan Ekonomi Di Indonesia Periode 2014-2018. Inovator : Jurnal Manajemen. Vol. 8 No.2, 13-24.

Permatasari, K. (2020). Pengaruh Pembayaran Non Tunai Terhadap Variabel Makroekonomi di Indonesia Tahun 2010-2017. Jurnal Ilmu Manajemen, Vol. 8 No. 1, 225-232.
Ramadani, L. (2016). Pengaruh Penggunaan Kartu Debit dan Uang Elektronik Terhadap Pengeluaran Konsumsi Mahasiswa. Jurnal Ekonomi dan Studi Pembangunan, Vol. 8 No.1, 1-8.

Saragih, A. H. (2018). Pengaruh Penrimaan Pajak Terhadap Pertumbuhan Ekonomi Di Indonesia. Sistem Informasi, Keuangan, Auditing dan Perpajakan, 17-27.

Setiabudi, A. W. (2017). Rasio Pajak Optimal dan Tingkat Pertumbuhan Ekonomi di Indonesia Tahun 19702008. Jurnal Akuntansi, Vol.10 No.2, 151-179.

Siahaan, S., Purba, E., \& Simangunsong, R. M. (2001). Pengantar Ekonomi Pembangunan. Medan: Universitas HKBP Nommensen.

Sreenu, N. (2020). Cashless Payment Policy and Its Effects on Economic Growth of India: An Exploratory Study. ACM Transactions on Management Information Systems. Vol. 11 No. 3, 15-24.

Suhartanto, D. (2020). Analisis Data untuk Riset Bisnis: SPSS, AMOS, PLS

Edisi 2. Bandung: Politeknik Negeri Bandung.

Sumon, K. K., \& Miyan, M. S. (2017). Inflation and Economic Growth: An Empirical Evidence of Bangladesh (1986-2016). International Journal of Economics and Financial. Vol.7 No.5, 454464.

Susilawati, \& Putri, D. Z. (2019). Analisis Pengaruh Transaksi Non Tunai dan Suku Bunga BI Terhadap Pertumbuhan Ekonomi di Indonesia. Jurnal Kajian Ekonomi dan Pembangunan. Vol.1 No.2, 667-678.

Tee, H. H., \& Ong, H. B. (2016). Cashless payment and economic growth. Financial Innovation, 1-9.

Utari, G. D., Cristina, R., \& Pambudi, S. (2015). Inflasi Di Indonesia: 
Karakteristik dan

Pengendaliannya. Jakarta: BI

Institute.

Yulianti, R., \& Khairuna. (2019).

Pengaruh Inflasi Terhadap

Pertumbuhan Ekonomi Provinsi

Aceh Periode 2015-2018 Dalam

Prespektif Ekonomi Islam. Jurnal

Akuntansi Mmuhammadiyah. Vol.9

No.2, 113-123. 